\title{
Geriatric epistaxis: Management of epistaxis in the geriatric patient group
}

\author{
Geriatrik epistaksis: Geriatrik hasta grubunda epistaksis yönetimi
}

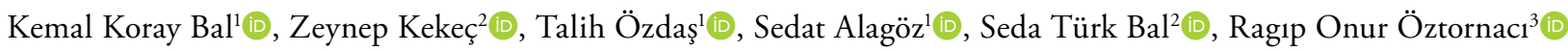 \\ ${ }^{1}$ Department of Otolaryngology, University of Health Sciences Adana City Hospital, Adana, Turkey \\ ${ }^{2}$ Department of Emergency Medicine, Çukurova University Faculty of Medicine, Adana, Turkey \\ ${ }^{3}$ Department of Biostatistics and Medical Informatics, Mersin University Faculty of Medicine, Mersin, Turkey
}

\begin{abstract}
Objectives: In this study, given the recent increases in the geriatric population and the consequent impacts on healthcare services, we examined the characteristics of geriatric patients admitted to the emergency department due to epistaxis.

Patients and Methods: This retrospective study included 55 patients (33 males, 22 females; mean age: $72 \pm 6.8$ years; range, 65 to 93 years) with epistaxis admitted to the Cukurova University Emergency Medicine Department and University of Health Sciences Adana City Training and Research Hospital Otolaryngology Emergency Polyclinic between 01.05.201901.04.2020. The patients were divided into two groups according to age: Group 1 consisted of patients aged 65 to 75 years; Group 2 consisted of patients over 75. Postoperative bleeding and trauma history were excluded in all patients in the study.
\end{abstract}

Results: There were no significant differences between the two groups regarding the rate of hospital discharge $(\mathrm{p}=1.00)$. Patients with posterior hemorrhage and posterior nasal tampons required significantly more hospitalizations $(\mathrm{p}<0.001)$.

Conclusion: The presence of comorbidities and drug use may cause persistent and recurrent epistaxis. It is necessary for physicians to be more cautious about the use of off-label antiaggregants and anticoagulants.

Keywords: Drug-related side effects and adverse reactions, emergencies, epistaxis, geriatrics, otorhinolaryngologic diseases.
$\ddot{O} Z$

Amaç: Bu çalışmada geriatrik nüfustaki artış ve sağlık hizmetlerine olan etkisi göz önüne alındığında, burun kanaması nedeniyle acil servise başvuran geriatrik hastalar incelendi.

Hastalar ve Yöntemler: Bu retrospektif çalışmaya 01.05.201901.04.2020 tarihleri arasında Çukurova Üniversitesi Acil Tip Bölümü ve Sağlık Bilimleri Üniversitesi Adana Şehir Eğitim ve Araştırma Hastanesi Kulak Burun Boğaz Acil Polikliniğine burun kanaması şikayeti ile başvuran 55 hasta (33 erkek, 22 kadın; ort. yaş: $72 \pm 6.8$ yıl; dağılım, 65-93 yıl) dahil edildi. Hastalar yaşlarına göre iki gruba ayrıldı: Grup 1, 65-75 yaş arası hastalardan oluşturuldu ve Grup 2, 75 yaş üstü hastalardan oluşturuldu. Çalışmadaki tüm hastalarda ameliyat sonrası kanama ve travma öyküsü dışlandı.

Bulgular: Hastaneden taburcu olma oranı açısından iki grup arasında anlamlı fark yoktu $(\mathrm{p}=1.00)$. Posterior kanamalı ve posterior burun tamponlu hastalar anlamlı olarak daha fazla hastaneye yatış gerektirdi $(\mathrm{p}<0.001)$.

Sonuç: Komorbiditelerin varlığı ve ilaç kullanımı kalıcı ve tekrarlayan burun kanamasına neden olabilir. Endikasyon dışı antiaggreganların ve antikoagülanların kullanımına dikkat etmek gerekmektedir.

Anahtar sözcükler: İlaç ilişkili yan etkiler ve istenmeyen reaksiyonlar, aciller, epistaksis, geriatri, otorinolaringoloji hastalıkları. 
Approximately $60 \%$ of the population will experience epistaxis in their lifetime, with $6 \%$ requiring treatment. ${ }^{[1]}$ Epistaxis occurs at all ages; however, it is more prevalent among children under 10 and adults over 40. Although epistaxis occurs in all age groups, its incidence sharply increases in the elderly. ${ }^{[2]}$

Epistaxis has many local and systemic causes; however, no specific etiology is detected in most patients. The causes of epistaxis are hypertension (HT), the use of certain drugs, such as coumadin, nonsteroidal anti-inflammatory drugs (NSAIDs), and acetylsalicylic acid (ASA), coagulopathies, hematological malignancies, hepatobiliary diseases, vascular/connective tissue diseases, organ failure, and malnutrition. ${ }^{[3]}$

The widespread use of clot-disrupting drugs, such as ASA and warfarin (WF), in the elderly may contribute to the high incidence of epistaxis and the severity of bleeding. ${ }^{[4]}$ Approximately $90 \%$ of epistaxis episodes originate from Kiesselbach's plexus and present as anterior bleeding along the anterior nasal septum; approximately $10 \%$ of epistaxis episodes occur as posterior bleeding. ${ }^{[5]}$

Most patients with epistaxis can be treated by chemical cauterization, administration of a hemostatic agent, and application of an anterior nasal buffer. However, 5 to $10 \%$ of patients have posterior epistaxis, which cannot be cured by these methods. To address this shortcoming, we focused on the characteristics of this patient group. Although posterior nasal tampons may be used in patients with posterior epistaxis, in recent years, both the morbidity rates and hospitalization duration of these patients have decreased due to the use of transnasal endoscopic sphenopalatine artery ligation (TESPAL) and arterial embolization. ${ }^{[6]}$ While individuals aged over 70 are at a higher risk of epistaxis, they are three times more likely to receive medical care for epistaxis than pediatric patients. ${ }^{[7]}$

Our aim is to define additional features of epistaxis patients in the geriatric population and to have an administrative idea.

\section{PATIENTS AND METHODS}

This retrospective study included 55 patients (33 males, 22 females; mean age $72 \pm 6.8$ years; range, 65 to 93 years) admitted to the Cukurova University Emergency Medicine and University of Health Sciences Adana City Training and Research Hospital Otolaryngology Emergency Polyclinic between 01.05.2019 and 01.04.2020 with a complaint of epistaxis. The patients were divided into two groups according to age. Group 1 consisted of 43 patients (78.2\%) aged between 65-75 years; Group 2 consisted of 12 patients (21.8\%) aged over 75. Approval for the study was obtained from the Adana City Training and Research Hospital Clinical Research Ethics Committee on 08.04.2020 (decision number 783). Written consent was obtained from each patient participating in the study.

Data on systolic and diastolic blood pressure values and the presence of systemic diseases were recorded from the patients' records at the time of application. Systemic diseases are classified as hemato-oncological diseases (HODs), HT, diabetes mellitus (DM), atherosclerosis, coronary artery disease (CAD), and chronic obstructive pulmonary disease (COPD) necessitating nebulizer use. Hemato-oncological diseases are myelodysplastic syndrome (MDS), acute myelogenous leukemia (AML), chronic myelogenous leukemia (CML), hemophilia $\mathrm{B}$, and lung cancer (LC).

Patients' use of ASA, WF, clopidogrel (CLP), and new oral anticoagulants (NOAC), a new-generation oral anticoagulant, was recorded. The total blood count, biochemical parameters, bleeding time, international normalized ratio, and activated partial thromboplastin time were recorded. Moreover, information regarding whether blood product replacement was performed (erythrocyte suspension [ES], apheresis platelet [AP], and fresh frozen plasma [FFP]) was recorded.

Medical interventions were grouped into (i) anterior nasal buffer use; (ii) posterior nasal buffer use; (iii) cauterization (chemical cauterization using silver nitrate and electrocauterization); (iv) TESPAL; and (v) angioembolization. Patients requiring surgical intervention were grouped according to the use of local and general anesthesia.

\section{Statistical analysis}

Statistical analysis of the data was performed using IBM SPSS version 21.0 software (IBM Corp., Armonk, NY, USA). Descriptive statistics are presented as mean \pm standard deviation for the continuous variables and the totals and percentages for the categorical variables. The chi-square test was used to analyze the categorical variables. The Shapiro-Wilk test and KolmogorovSmirnov test were used to confirm the normality of the continuous variables. Parametric tests were used to analyze variables that conformed to a normal distribution, while nonparametric tests were used to analyze variables that did not conform to a normal distribution. The statistical significance level for all the analyses was set at a $p$ value of $<0.05$. 


\section{RESULTS}

A total of $48(87.3 \%)$ patients had at least one systemic disease; of these, 31 (56.3\%) had more than one systemic disease. The most common comorbidity was HT, affecting 34 patients (61.8\%). Other comorbidities were CAD (40\%), DM (18.2\%), COPD (12.7\%), and HOD (10.9\%) (Figure 1). The distribution of HODs among the patients was as follows: MDS, one (1.8\%) patient; AML, one (1.8\%) patient; CML, two (3.6\%) patients; hemophilia B, one (1.8\%) patient; and LC, one $(1.8 \%)$ patient.

Eighteen (32.7\%) patients used antiaggregants, and six (10.9\%) patients used anticoagulants. Moreover, 13 (23.6\%) patients used ASA; three (5.5\%) patients used CLP; two (3.6\%) patients used ASA + CLP; four (7.3\%) patients used WF; and two (3.6\%) patients used NOAC (Figure 2). Three (5.4\%) patients using ASA and one (1.8\%) patient using CLP had no indications of antiaggregant use. In total, $7.2 \%$ of the patients admitted with epistaxis had drug use without indication.

At the initial application, the systolic blood pressure of the patients was between 80 and $200 \mathrm{mmHg}$, with a mean of $139.7 \pm 25.4 \mathrm{mmHg}$. Moreover, the diastolic blood pressure of the patients was 50 to $120 \mathrm{mmHg}$, with a mean of $77.7 \pm 14.6 \mathrm{mmHg}$.

Five (9\%) patients had experienced repeated hospitalizations (three patients from Group 1 and two patients from Group 2). Hypertension was observed in $60 \%$ of the re-admitted patients. Antiaggregant and anticoagulant use was observed in $60 \%$ of the re-admitted patients. In total, $40 \%$ of these patients were hospitalized.

Forty-seven (85.5\%) patients had anterior bleeding and eight (14.5\%) had posterior bleeding. Nasal tampons were applied to nine (16.3\%) patients. Of these, one (1.8\%) patient received anterior nasal tampons, while eight (14.5\%) patients received anterior and posterior nasal tampons. Posterior nasal tampons were applied to

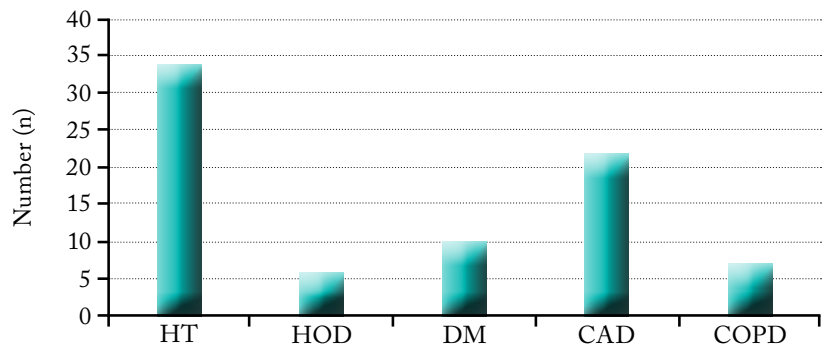

Figure 1. Frequency of systemic disease in patients.

HT: Hypertension; HOD: Hemato-oncological disease; DM: Diabetes mellitus; CAD: Coronary artery disease; COPD: Chronic obstructive pulmonary disease. each patient with posterior hemorrhage (14.5\%) and the patients were then hospitalized. A total of 47 (85.5\%) patients were discharged after the first intervention and their bleeding was controlled. Chemical cauterization was performed in one (1.8\%) patient using silver nitrate, while electrocauterization was performed in two (3.6\%) patients with bipolar cautery. One (1.8\%) patient underwent TESPAL, while one (1.8\%) patient underwent angioembolization. Electrocauterization with bipolar cautery was performed in two (3.6\%) patients under local anesthesia, TESPAL was performed in one $(1.8 \%)$ patient under general anesthesia, and angioembolization was performed in one (1.8\%) patient under general anesthesia. Four (7.3\%) patients underwent invasive or surgical procedures under general anesthesia.

In total, 12 units of blood products were replaced in six patients. Apheresis platelet was the most required replacement product (5 units; 41.6\%). The other replacement products were ES (4 units) and FFP (3 units).

Eight patients were hospitalized from three to 10 days, with a mean of $6.5 \pm 2.4$ days. Of these, seven $(87.5 \%)$ patients had systemic disease, while one $(12.5 \%)$ had no systemic disease. One (12.5\%) patient who was hospitalized was using ASA, while one (12.5\%) patient was using ASA + CLP. It was observed that one (12.5\%) patient was hospitalized and one (12.5\%) patient underwent angioembolization; the other patients did not undergo any surgical or invasive procedures. Two (25\%) hospitalized patients received blood product replacement. Two units of AP were given to MDS patients, while one unit of AP and one unit of FFP were given to patients using ASA + CLP. No deaths due to epistaxis were noted in this study.

There was no significant difference between Group 1 and Group 2 regarding the rate of hospital discharge $(p=1.00)$. Patients with posterior hemorrhage and posterior nasal tampons had significantly more hospitalizations $(\mathrm{p}<0.001$, Table 1$)$.

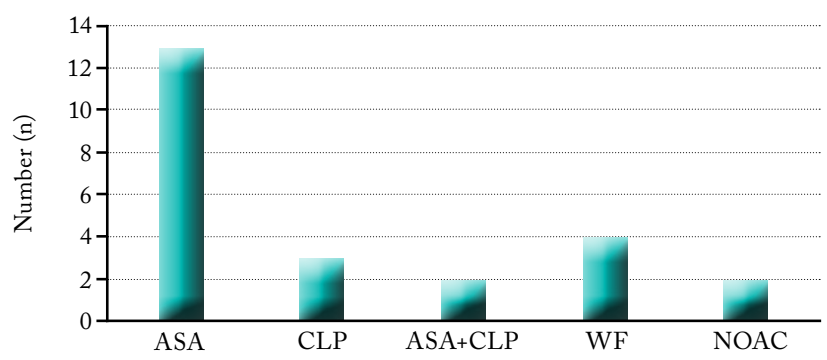

Figure 2. Frequency of antiaggregant and anticoagulant use in patients.

ASA: Acetylsalicylic acid; CLP: Clopidogrel; WF: Warfarin; NOAC: New oral anticoagulant. 


\begin{tabular}{|c|c|c|c|c|c|}
\hline \multicolumn{6}{|c|}{$\begin{array}{c}\text { Table } 1 \\
\text { P values in terms of hospitalization-discharge }\end{array}$} \\
\hline & \multicolumn{4}{|c|}{ Hospitalization } & \multirow[b]{3}{*}{$p$} \\
\hline & \multicolumn{2}{|c|}{ Hospitalization } & \multicolumn{2}{|c|}{ Discharge } & \\
\hline & $\mathrm{n}$ & $\%$ & $\mathrm{n}$ & $\%$ & \\
\hline Sex & & & & & 0.244 \\
\hline Male & 3 & 37.5 & 30 & 63.8 & \\
\hline Female & 5 & 62.5 & 17 & 36.2 & \\
\hline Groups (age, year) & & & & & 1.00 \\
\hline $65-75$ & 6 & 75.0 & 37 & 78.7 & \\
\hline$>75$ & 2 & 25.0 & 10 & 21.3 & \\
\hline Additional diseases & & & & & 1.00 \\
\hline No & 1 & 12.5 & 6 & 12.8 & \\
\hline Yes & 7 & 87.5 & 41 & 87.2 & \\
\hline Hypertension & & & & & 0.236 \\
\hline No & 5 & 62.5 & 16 & 34.0 & \\
\hline Yes & 3 & 37.5 & 31 & 66.0 & \\
\hline Diabetes mellitus & & & & & 0.326 \\
\hline No & 8 & 100.0 & 37 & 78.7 & \\
\hline Yes & 0 & 0.0 & 10 & 21.3 & \\
\hline Antiaggregant & & & & & 1.00 \\
\hline No & 6 & 75.0 & 31 & 66.0 & \\
\hline Yes & 2 & 25.0 & 16 & 34.0 & \\
\hline Anticoagulant type & & & & & 0.367 \\
\hline No & 8 & 100.0 & 41 & 87.2 & \\
\hline Warfarin & 0 & 0.0 & 4 & 8.5 & \\
\hline NOAC & 0 & 0.0 & 2 & 4.3 & \\
\hline Antiaggregant type & & & & & 0.392 \\
\hline No & 6 & 75.0 & 31 & 66.0 & \\
\hline Clopidogrel & 0 & 0.0 & 3 & 6.4 & \\
\hline ASA & 1 & 12.5 & 12 & 25.5 & \\
\hline ASA+clopidogrel & 1 & 12.5 & 1 & 2.1 & \\
\hline COPD & & & & & 1.00 \\
\hline No & 7 & 87.5 & 41 & 87.2 & \\
\hline Yes & 1 & 12.5 & 6 & 12.8 & \\
\hline CAD & & & & & 0.454 \\
\hline No & 6 & 75.0 & 27 & 57.4 & \\
\hline Yes & 2 & 25.0 & 20 & 42.6 & \\
\hline Anticoagulant & & & & & 0.577 \\
\hline No & 8 & 100.0 & 41 & 87.2 & \\
\hline Yes & 0 & 0.0 & 6 & 12.8 & \\
\hline Bleeding type & & & & & $<0.001$ \\
\hline Posterior & 8 & 100.0 & 0 & 0.0 & \\
\hline Anterior & 0 & 0.0 & 47 & 100.0 & \\
\hline Surgery & & & & & 0.477 \\
\hline No & 7 & 87.5 & 44 & 93.6 & \\
\hline Yes & 1 & 12.5 & 3 & 6.4 & \\
\hline
\end{tabular}


It was concluded that the presence of comorbidities, sex, and antiaggregant and anticoagulant use did not have a significant effect on the rate of hospital discharge, as shown in the table below.

\section{DISCUSSION}

Epistaxis is responsible for one in 200 emergency room visits in the USA ${ }^{[7]}$ In the general community, $60 \%$ of the population experience epistaxis during their lifetime, and $6 \%$ of these individuals require medical treatment. ${ }^{[8]}$

Pallin et al.'s ${ }^{[7]}$ study of 4,503,000 epistaxis patients showed that age-related bimodal distribution was observed, and the frequency of epistaxis occurrence was found to be $1.2 \%$ in those aged 70 to 79 years. Our study included $43(78.2 \%)$ patients aged between 65 and 75 and $12(21.8 \%)$ patients aged over 75 .

In Sireci's ${ }^{[9]}$ study of 281 patients, anterior nasal tampons were applied to 249 (88.6\%) patients; in contrast, our study involved tampons being applied to nine $(16.3 \%)$ patients. Of these, one $(1.8 \%)$ patient received an anterior nasal tampon, while eight (14.5\%) patients received anterior and posterior nasal tampons.

There are studies with a large number of patients: the study of Zahed ${ }^{[10]}$ with 124 participants, Buchberger ${ }^{[11]}$ with 600 participants, and Biggs ${ }^{[12]}$ with 100 participants. In comparison, the present study included just 55 patients as we included only elderly patients, a special patient group. Yüksel's ${ }^{[13]}$ study sampled 67 female (57.2\%) and 50 male (42.7\%) patients, all of whom were over 65 , with a mean age of 73.51 years. In contrast, in the present study, $60 \%$ of the patients were male and $40 \%$ were female, aged between 65 and 93 years, with a mean age of $72 \pm 6.8$. In Yüksel's ${ }^{[13]}$ study, $80.3 \%$ of the patients had comorbidities, with the most common comorbidity being HT. In 30 disease studies conducted by Ismi, ${ }^{[6]}$ the prevalence of HT was $56.6 \%$. The prevalence of HT in patients with epistaxis varies between 24 and $64 \%{ }^{[14]}$ Although some studies have revealed a relationship between HT and epistaxis, others have found no relationship between the severity of bleeding and HT. In addition, other researchers have suggested that HT is caused by anxiety in patients with epistaxis. ${ }^{[15-17]}$ In our study, $87.3 \%$ of the patients had comorbidities and $61.8 \%$ had HT. Ridker ${ }^{[18]}$ found a significantly higher risk of epistaxis in those using ASA in a study involving females over 45 prescribed with $100 \mathrm{mg}$ of ASA ( $\mathrm{p}<0.001)$. In Biggs's ${ }^{[12]}$ study, the use of antiaggregants or anticoagulants was $58 \%$, while the rate was $43.6 \%$ in our study.
The first step in treating epistaxis is determining the bleeding locus. Yüksel ${ }^{[13]}$ detected anterior hemorrhage in $76.9 \%$ of patients sampled. This is consistent with other values reported in the literature. In our study, the locus of bleeding was the anterior region in $85.4 \%$ of patients. In the literature, the incidence of posterior hemorrhage is approximately $10 \% ;^{[19]}$ in contrast, this rate was $14.6 \%$ in the present study. Chemical cauterization using silver nitrate or electrocauterization with bipolar cautery may be performed after the bleeding locus has been identified. Chemical cauterization may be performed in patients with minor anterior bleeding, while electrocauterization may be performed in patients with slightly more severe bleeding. The procedure should be performed unilaterally to avoid perforating the septum. To date, no study has demonstrated the superiority of electrocauterization over chemical cauterization. ${ }^{[20,21]}$ In our study, chemical cauterization was performed in one (1.8\%) patient and electrocauterization was performed in two (3.6\%) patients with bipolar cautery. Transnasal endoscopic sphenopalatine artery ligation and angioembolization can be performed to control stubborn bleeding. Angioembolization for posterior epistaxis was described in 1974, with success rates between 79 and $96 \% \cdot{ }^{[22,23]}$ In a study involving 127 patients, the success rate of TESPAL was reported to be $98 \% .{ }^{[24]}$ In our study, angioembolization was performed in one $(1.8 \%)$ patient and TESPAL was performed in one $(1.8 \%)$ patient. No complications or ongoing bleeding were observed after the procedure in these two patients with posterior hemorrhage.

In Buchberger's ${ }^{[11]}$ study, secondary epistaxis was detected in $20.5 \%$ of patients, with blood pressure readings of over $140 / 90 \mathrm{mmHg}$. In our study, the systolic blood pressure of the patients was between 80 and $200 \mathrm{mmHg}$, with a mean value of $139.7 \pm 25.4 \mathrm{mmHg}$. Moreover, the diastolic blood pressure of the patients was between 50 and $120 \mathrm{mmHg}$, with a mean of $77.7 \pm 14.6 \mathrm{mmHg}$.

Baugh's ${ }^{[25]}$ study, which examined 11,366 cases of pediatric epistaxis, revealed that more blood and blood product transfusions were required in patients with only a nasal tampon than in patients with ligation or angioembolization. In our study, six (10.9\%) patients received blood and blood products. Two (3.6\%) of these patients were buffered, and there was no need for transfusion in those who underwent TESPAL or angioembolization. In Yüksel's ${ }^{[13]}$ study $17.9 \%$ of the patients were hospitalized. In our study, $14.5 \%$ of the patients were hospitalized with a mean hospitalization duration of six days. 
The limitation of our study is the small number of patients. Multicenter, long-term studies can be planned to increase the number of patients.

In conclusion, epistaxis represents an ENT emergency in the geriatric population. The presence of comorbidities and drug use may cause persistent and recurrent epistaxis. In light of this, physicians should be cautious about prescribing off-label antiaggregants and anticoagulants. Patients and their relatives should be warned about the regulation of HT.

\section{Declaration of conflicting interests}

The authors declared no conflicts of interest with respect to the authorship and/or publication of this article.

\section{Funding}

The authors received no financial support for the research and/or authorship of this article.

\section{REFERENCES}

1. Small M, Murray JA, Maran AG. A study of patients with epistaxis requiring admission to hospital. Health Bull (Edinb) 1982;40:20-9.

2. Tomkinson A, Roblin DG, Flanagan P, Quine SM, Backhouse S. Patterns of hospital attendance with epistaxis. Rhinology 1997;35:129-31.

3. Simmen DB, Jones NS. Epistaxis. In: Flint PW, Haughey BH, Lund V, Niparko JK, Robbins KT, Thomas JR, et al., editors. Cummings otolaryngology. 6th ed. Philadelphia: Saunders; 2015. p. 678-90.

4. Smith DS, Wax MK. Epistaxis in the Geriatric Population. In: Calhoun KH, Eibling DE, editors. Geriatric Otolaryngology. New York: Taylor \& Francis Group; 2006. p. 239-47.

5. Viehweg TL, Roberson JB, Hudson JW. Epistaxis: Diagnosis and treatment. J Oral Maxillofac Surg 2006;64:511-8.

6. İsmi O, Vayisoğlu Y, Özcan C, Görür K, Ünal M. Endoscopic sphenopalatine artery ligation in posterior epistaxis: Retrospective analysis of 30 patients. Turk Arch Otorhinolaryngol 2016;54:47-52.

7. Pallin DJ, Chng YM, McKay MP, Emond JA, Pelletier AJ, Camargo CA Jr. Epidemiology of epistaxis in US emergency departments, 1992 to 2001. Ann Emerg Med 2005;46:77-81.

8. Yau S. An update on epistaxis. Aust Fam Physician 2015;44:653-6.

9. Sireci F, Speciale R, Sorrentino R, Turri-Zanoni M, Nicolotti M, Canevari FR. Nasal packing in sphenopalatine artery bleeding: Therapeutic or harmful? Eur Arch Otorhinolaryngol 2017;274:1501-5.
10. Zahed R, Mousavi Jazayeri MH, Naderi A, Naderpour Z, Saeedi M. Topical tranexamic acid compared with anterior nasal packing for treatment of epistaxis in patients taking antiplatelet drugs: Randomized controlled trial. Acad Emerg Med 2018;25:261-6.

11. Buchberger AMS, Baumann A, Johnson F, Peters $\mathrm{N}$, Piontek G, Storck K, et al. The role of oral anticoagulants in epistaxis. Eur Arch Otorhinolaryngol 2018;275:2035-43.

12. Biggs TC, Baruah P, Mainwaring J, Harries PG, Salib RJ. Treatment algorithm for oral anticoagulant and antiplatelet therapy in epistaxis patients. J Laryngol Otol 2013;127:483-8.

13. Yüksel A, Kurtaran H, Kankiliç ES, Ark N, Uğur KS, Gündüz M. Epistaxis in geriatric patients. Turk J Med Sci 2014;44:133-6.

14. Herkner H, Havel C, Müllner M, Gamper G, Bur A, Temmel AF, et al. Active epistaxis at ED presentation is associated with arterial hypertension. Am J Emerg Med 2002;20:92-5.

15. Herkner H, Laggner AN, Müllner M, Formanek M, Bur A, Gamper G, et al. Hypertension in patients presenting with epistaxis. Ann Emerg Med 2000;35:126-30.

16. Lubianca Neto JF, Fuchs FD, Facco SR, Gus M, Fasolo $\mathrm{L}$, Mafessoni R, et al. Is epistaxis evidence of end-organ damage in patients with hypertension? Laryngoscope 1999;109:1111-5.

17. Alvi A, Joyner-Triplett N. Acute epistaxis. How to spot the source and stop the flow. Postgrad Med 1996;99:8390.

18. Ridker PM, Cook NR, Lee IM, Gordon D, Gaziano JM, Manson JE, et al. A randomized trial of low-dose aspirin in the primary prevention of cardiovascular disease in women. N Engl J Med 2005;352:1293-304.

19. Bhatnagar RK, Berry S. Selective surgicel packing for the treatment of posterior epistaxis. Ear Nose Throat J 2004;83:633-4.

20. Hanif J, Tasca RA, Frosh A, Ghufoor K, Stirling R. Silver nitrate: Histological effects of cautery on epithelial surfaces with varying contact times. Clin Otolaryngol Allied Sci 2003;28:368-70.

21. Middleton PM. Epistaxis. Emerg Med Australas 2004;16:428-40.

22. Sokoloff J, Wickbom I, McDonald D, Brahme F, Goergen TC, GoldbergerLE. Therapeutic percutaneous embolization in intractable epistaxis. Radiology 1974;111:285-7.

23. Smith TP. Embolization in the external carotid artery. J Vasc Interv Radiol 2006;17:1897-912.

24. Kumar S, Shetty A, Rockey J, Nilssen E. Contemporary surgical treatment of epistaxis. What is the evidence for sphenopalatine artery ligation? Clin Otolaryngol Allied Sci 2003;28:360-3.

25. Baugh TP, Chang CWD. Epidemiology and management of pediatric epistaxis. Otolaryngol Head Neck Surg 2018;159:712-6. 